\title{
Melatonin as a potential anticarcinogen for non-small-cell lung cancer
}

\author{
Zhiqiang Ma ${ }^{1, *}$, Yang Yang ${ }^{2,3}{ }^{*}$, Chongxi Fan ${ }^{1, *}$, Jing Han ${ }^{4}$, Dongjin Wang ${ }^{2}$, Shouyin \\ $\mathrm{Di}^{1}$, Wei Hu${ }^{2}$, Dong Liu ${ }^{5}$, Xiaofei $\mathbf{L i}^{1}$, Russel J. Reiter ${ }^{6}$ and Xiaolong Yan ${ }^{1}$ \\ ${ }^{1}$ Department of Thoracic Surgery, Tangdu Hospital, The Fourth Military Medical University, Xi'an, China \\ 2 Department of Thoracic and Cardiovascular Surgery, Affiliated Drum Tower Hospital of Nanjing University Medical School, \\ Nanjing, Jiangsu, China \\ ${ }^{3}$ Department of Biomedical Engineering, The Fourth Military Medical University, Xi'an, China \\ ${ }^{4}$ Department of Ophthalmology, Tangdu Hospital, The Fourth Military Medical University, Xi'an, China \\ ${ }^{5}$ State Key Laboratory of Cardiovascular Disease, Fuwai Hospital, National Center for Cardiovascular Diseases, Chinese \\ Academy of Medical Sciences \& Peking Union Medical College, Beijing, China \\ ${ }^{6}$ Department of Cellular and Structural Biology, UT Health Science Center, San Antonio, TX, USA \\ * These authors have contributed equally to this work. \\ Correspondence to: Xiaolong Yan, email: xiaolongyanfmmu@126.com \\ Russel J. Reiter, email: reiter@uthscsa.edu \\ Xiaofei Li, email: xiaofeilitangdu@126.com
}

Keywords: melatonin; non-small-cell lung cancer; oncostatic effects; drug synergy; potential directions

Received: December 08, $2015 \quad$ Accepted: March 31,2016 Published: April 18, 2016

\section{ABSTRACT}

Non-small-cell lung cancer (NSCLC) is a leading cause of death from cancer worldwide. Melatonin, an indoleamine discovered in the pineal gland, exerts pleiotropic anticancer effects against a variety of cancer types. In particular, melatonin may be an important anticancer drug in the treatment of NSCLC. Herein, we review the correlation between the disruption of the melatonin rhythm and NSCLC incidence; we also evaluate the evidence related to the effects of melatonin in inhibiting lung carcinogenesis. Special focus is placed on the oncostatic effects of melatonin, including anti-proliferation, induction of apoptosis, inhibition of invasion and metastasis, and enhancement of immunomodulation. We suggest the drug synergy of melatonin with radio- or chemotherapy for NSCLC could prove to be useful. Taken together, the information complied herein may serve as a comprehensive reference for the anticancer mechanisms of melatonin against NSCLC, and may be helpful for the design of future experimental research and for advancing melatonin as a therapeutic agent for NSCLC.

\section{INTRODUCTION}

Lung cancer, which accounts for about $13 \%$ of total cancer diagnoses, is the most frequently diagnosed cancer and the leading cause of cancer death among males and females [1]. More than $85 \%$ of lung cancer cases are classified as non-small-cell lung cancer (NSCLC) [2], of which the predicted 5-year survival rate is only $15.9 \%$ [3]. Surgery and chemoradiotherapy are the two major treatments to prolong the survival of NSCLC patients, but improvements are marginally effective [4]. Moreover, radio- or chemotherapies often lead to undesirable side effects on normal cells or tissues, which limits their use as a treatment for cancer [5]. Thus, a number of studies were devoted to overcoming the deleterious effects and enhancing the efficacy of these treatments when given in combination with the appropriate supplement such as melatonin, which is well known lack of toxic and 
Table 1: Melatonin disruption and NSCLC

\begin{tabular}{|c|c|c|c|}
\hline Research object & Measures & Outcome & References \\
\hline \multicolumn{4}{|l|}{ Epidemiologic surveys } \\
\hline $\begin{array}{l}761 \text { male lung } \\
\text { cancers (142 small- } \\
\text { cell carcinomas, } 149 \\
\text { adenocarcinomas, } \\
314 \text { squamous cell } \\
\text { carcinoma and } 156 \\
\text { others }) \text { and } 512 \\
\text { controls in Montreal }\end{array}$ & Face to Face interviews & $\begin{array}{l}\text { Compared with men who never worked at night, } \\
\text { the adjusted OR among men who ever worked } \\
\text { at night was } 1.76(95 \% \mathrm{CI}: 1.25,2.47) \text { for lung } \\
\text { cancer. According to main histologic subtype, } \\
\text { adjusted ORs were } 1.91(95 \% \mathrm{CI}: 1.27,2.87) \text { for } \\
\text { squamous cell carcinoma, } 1.62(95 \% \mathrm{CI}: 1.25 \text {, } \\
2.47) \text { for small-cell carcinoma, and } 1.46(95 \% \mathrm{CI} \text { : } \\
0.86,2.50) \text { for adenocarcinoma }\end{array}$ & $\begin{array}{l}\text { Parent et al. } \\
{[50]}\end{array}$ \\
\hline \multicolumn{4}{|l|}{ Experimental studies } \\
\hline $\begin{array}{l}\text { Female } \text { BD2F1 mice } \\
\text { with subcutaneous } \\
\text { propagation of Lewis } \\
\text { lung carcinoma }\end{array}$ & $\begin{array}{l}\text { Tumor inoculation and } \\
\text { melatonin treatment }(1.25 \mathrm{mg} / \\
\text { kg/night) were performed } 2 \\
\text { months after pinealectomy }\end{array}$ & $\begin{array}{l}\text { Melatonin treatment decreased metastasis with } \\
\text { consequent restoration of thymic efficiency, } \\
\text { negative crude zinc balance and IL-2 production } \\
\text { in compare with controls }\end{array}$ & $\begin{array}{l}\text { Mocchegiani } \\
\text { et al. }[32]\end{array}$ \\
\hline \multicolumn{4}{|c|}{\begin{tabular}{|l|l|l|}
$\begin{array}{l}\text { Melatonin level in lung } \\
\text { cancer patients }\end{array}$ & \\
\end{tabular}} \\
\hline 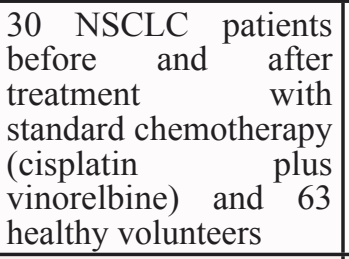 & $\begin{array}{l}\text { Blood samples were collected } \\
\text { at } 12 \text { noon and } 12 \text { midnight. } \\
\text { Urine samples were collected } \\
\text { at } 7 \text { AM and } 4 \text { PM }\end{array}$ & $\begin{array}{l}\text { Melatonin, its precursor tryptophan, and its major } \\
\text { metabolite, 6-sulfatoxymelatonin concentrations } \\
\text { were significantly lower in cancer patients, in } \\
\text { comparison with healthy subjects. Furthermore, } \\
\text { those concentrations progressively decreased after } \\
\text { standard chemotherapy in NSCLC patients }\end{array}$ & Hu et al. [54] \\
\hline $\begin{array}{l}17 \text { patients with stages } \\
\text { I and II of untreated } \\
\text { NSCLC, } 17 \text { patients } \\
\text { with stages III and IV } \\
\text { of untreated NSCLC, } \\
\text { and } 17 \text { controls }\end{array}$ & $\begin{array}{l}\text { Melatonin serum level was } \\
\text { measured in blood samples } \\
\text { collected every four hours for } \\
24 \text { hours }\end{array}$ & $\begin{array}{l}\text { Melatonin levels were lower in the patients } \\
\text { with NSCLC than in normal subjects, without a } \\
\text { significant difference between the two groups of } \\
\text { cancers, but a clear circadian rhythm was present } \\
\text { in the three groups }\end{array}$ & $\begin{array}{l}\text { Mazzoccoli et } \\
\text { al. [53] }\end{array}$ \\
\hline
\end{tabular}

undesirable side effects [5-8].

Melatonin (N-acetyl-5-methoxytryptamine) is an indoleamine produced by the pineal gland that modulates the human circadian rhythms and acts as a neuromodulator, cytokine, biological response modifier and antioxidant $[9,10]$. As a potent free radical scavenger and antioxidant, melatonin has the capacity to scavenge up to 10 reactive oxygen species (ROS) via the cascade reaction means, which distinguishes melatonin from the classic antioxidants that scavenge only one or less ROS [11-13]. Additionally, numerous publications have reported that melatonin inhibits the growth of a variety of cancers: lung [5, 14, 15], breast [16-20], prostate [21-24], liver [25, 26], colon [27, 28], etc. The oncostatic mechanisms of melatonin are related to several hallmarks of cancer, including anti-proliferation [14], induction of apoptosis $[5,14,15]$, inhibition of invasion and metastasis [29, 30], anti-angiogenesis [16, 31], and enhancement of immunomodulation [32] among others. Furthermore, clinical studies have demonstrated that melatonin treatment enhances the efficacy and reduces the side-effects of chemotherapy, prolongs survival time, and improves quality of life for NSCLC patients [8,33]. Accordingly, these findings attest to melatonin being a potential anticancer drug in the treatment of NSCLC and provide an inducement for further work in this area.

In this review, we focus on the therapeutic actions of melatonin as a treatment for NSCLC. First, consider the correlation between melatonin disruption and its impact on NSCLC incidence, and the anticarcinogenic effects of melatonin against lung cancer. We then describe in-depth the oncostatic effects of melatonin and the drug synergy of melatonin for NSCLC treatments. Finally, we discuss several novel potential directions for future research in this area. The information complied herein may serve as a comprehensive reference for the anticancer mechanisms of melatonin against NSCLC, and may be helpful for the design of future experimental research and for advancing melatonin as a therapeutic agent for NSCLC.

\section{MELATONIN DISRUPTION AND NSCLC}

Melatonin, the "chemical expression of darkness" [34], is an important component of the body's internal time-keeping system [35]. However, light exposure by artificial illumination at night suppresses human melatonin levels and disrupts circadian rhythmicity (mechanisms are illustrated in Figure 1) [36, 37]. Under controlled laboratory conditions, retinal exposure to illuminances as low as 1 lux or less of monochromatic light at wavelengths of 440 to 460 (blue-appearing light) significantly lowers nocturnal melatonin levels [38-40], as does $<100$ lux of broad spectrum fluorescent light [41-44]. Disturbances 
in melatonin circadian rhythm result in chronodisruption which is associated with many health disorders including heart diseases, neurodegenerative diseases, and cancer $[11,45]$. Epidemiological studies have demonstrated that melatonin disruption would increase the risk of cancers, including breast cancer [46-48], prostate cancer [49, 50], and colon cancer $[50,51]$, etc. Additionally, melatonin disruption also can increase the risk of NSCLC (Table 1). Parent et al. [50] reported that men who ever worked at night anytime as an adult have higher risk for lung cancer, with excesses apparent across all main histologic subtypes. Advanced NSCLC patients suffered from poor sleep quality and disrupted circadian function [52]. Data have revealed that melatonin levels are lower in NSCLC patients regardless of TNM stages [53]. Moreover, Hu et al. [54] demonstrated that melatonin and its metabolite, 6-sulfatoxymelatonin, are significantly lower in NSCLC patients with standard chemotherapy.

Collectively, the published literature suggested that melatonin disruption increases the risk of NSCLC. The mechanism involved, however, warrant further investigation. It is possible that melatonin anticarcinogenic actions may account for the increased incidence of NSCLC. This will be discussed later in this review.

\section{EFFECT OF MELATONIN ON LUNG CARCINOGENESIS}

Melatonin is an experimentally documented anticarcinogen against a number of cancers [55]. Previous animal studies have demonstrated that melatonin inhibits different chemical mutagen-induced carcinogenesis of breast [56-58], liver [59], colon [60, 61], uterine cervix and vagina [62]. Moreover, melatonin limits the lung carcinogenesis induced by urethane in $\mathrm{A} / \mathrm{J}$ and $\mathrm{SHR} / \mathrm{u}$ mice. When compared with the urethane-treated animals, melatonin treatment also significantly lowered concentration of serum malondialdehyde (MDA), an index of the lipid peroxidation (LPO), this indicated a potential role of melatonin as an antioxidant in relation to its cancer inhibiting actions [55, 63].

Cigarette smoke exposure, both active and passive, is a major epidemiologically proven cause of lung cancer; this accounts for about $90 \%$ of lung cancer incidence [64]. In the gaseous and particulate phases, cigarette smoke contains more than 4,500 components, including direct carcinogens (e.g., methylcholanthrene, benzo- $\alpha$-pyrenes and acrolein), toxins (e.g., carbon monoxide and nicotine), reactive solids with chemically catalytic surfaces, and oxidants (e.g., superoxide and nitrogen oxides) [65, 66]. Additionally, cigarette smoke is also considered as a critically-important risk factor in the development of chronic obstructive pulmonary diseases (COPD), which is another key risk factor for lung cancer $[64,66]$. Active smoking decreases human blood melatonin levels [67], while melatonin treatment attenuates cigarette smokeinduced pulmonary diseases and lung cancer mainly by three potential mechanisms (see Figure 2). First, melatonin may be useful in reducing lung tissue injury caused by smoke-related toxins (e.g., nicotine) [68, 69]. Furthermore, melatonin may decrease pulmonary inflammation induced as a consequence of smoking [70]. In cigarette smoke exposed mice, Shin et al. [71] reported that melatonin significantly reduced neutrophils counts, suppressed proinflammatory cytokines (TNF- $\alpha$, IL-1 $\beta$, IL-8, IL-6), and decreased matrix metalloproteinase (MMP)-9 and myeloperoxidase (MPO) expression in lung tissue. As an effective antioxidant, melatonin inhibition of oxidative

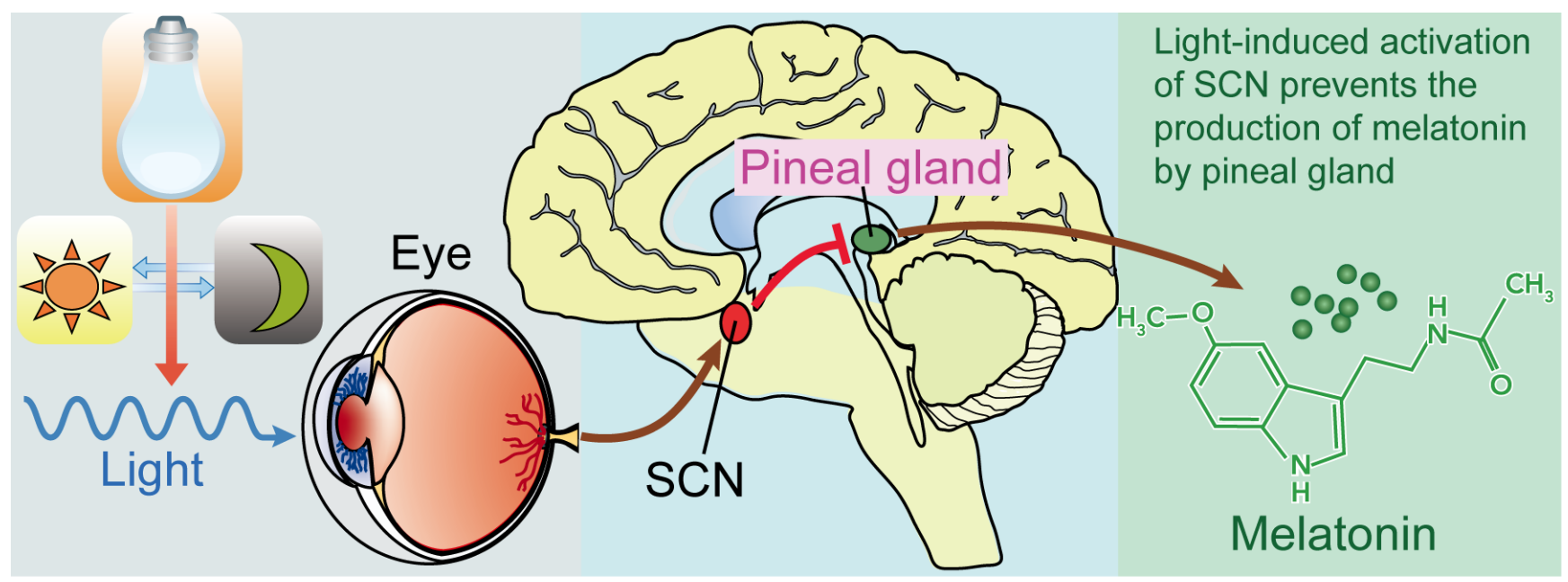

Figure 1: Light, suprachiasmatic nuclei (SCN), and the pineal/melatonin circuit. Melanopsin in retinal ganglion cells in the eye respond to light (natural or artificially) and transmit signals to the SCN. Then light-induced activation of the SCN prevents the pineal gland from producing melatonin and; conversely, melatonin production and secretion is increased during the dark period. 
stress induced by smoke is a potentially important protective means by which it reduces lung damage. In the lung tissue of smoke-treated animals, melatonin significantly reduced reactive oxygen species (ROS) and LPO production, and upregulated glutathione (GSH) and superoxide dismutase (SOD) activity $[68,71]$. Thus, the likelihood is high that melatonin reduces respiratory DNA damage caused by ROS, thereby inhibiting carcinogenesis [72]. The collective evidence suggests that melatonin should be considered a worthy agent for inhibition of lung cancer.

\section{EFFECT OF MELATONIN ON NSCLC CELL APOPTOSIS}

Resisting cell death is one of the hallmarks of cancer [73]. Apoptosis is a well-known mechanism of programmed cell death that does not injure normal neighboring cells and reduces local inflammation [74]. Since programmed cell death by apoptosis serves as a natural barrier to cancer development [73], apoptotic induction is an important mechanism initiated by chemotherapeutic agents [5]. Melatonin exerts antiapoptotic effects in normal cells exposed to toxic agents or metabolic injury. However, melatonin usually has the opposite effect on cancer cells and induces apoptosis in a wide range of different tumors (e.g., breast, prostate, cervix, liver, colon, pancreas, kidney, neuro) $[18,20,24$, $25,28,75-78]$; thus, the induction of apoptosis of cancer cells (but not of normal cells) is one of the mechanisms by which melatonin limits tumor growth [61, 79-88]. This specifically relates to lung cancer given that melatonin
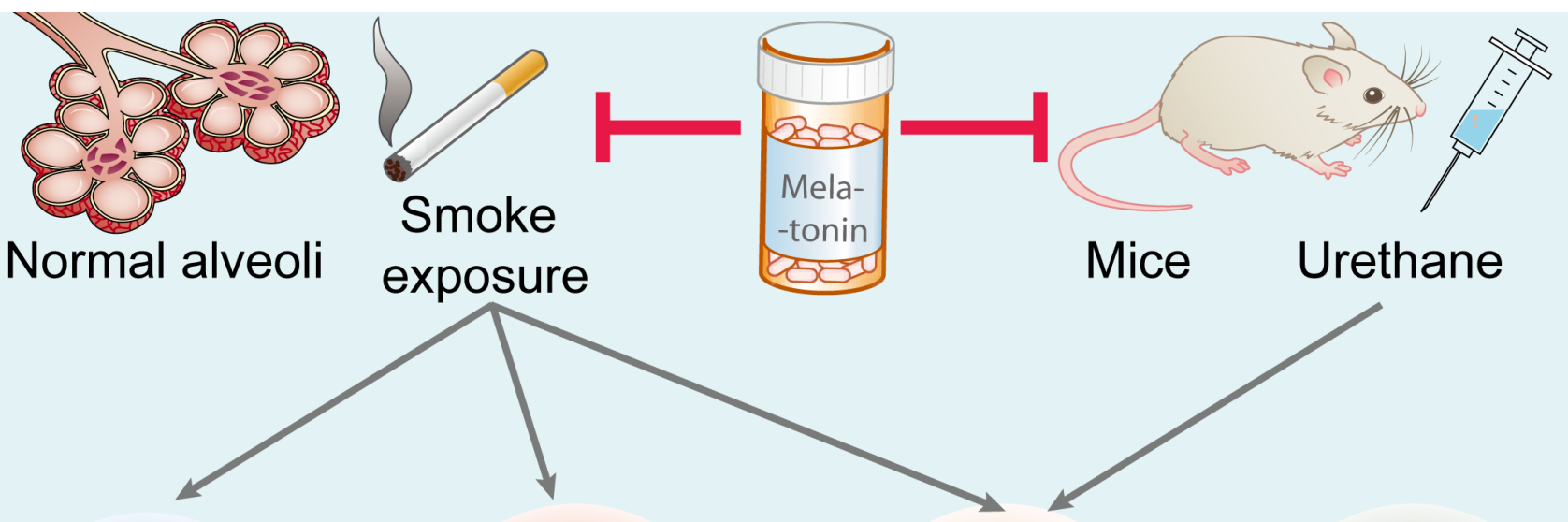

\section{Inflammation Oxidative stress DNA}
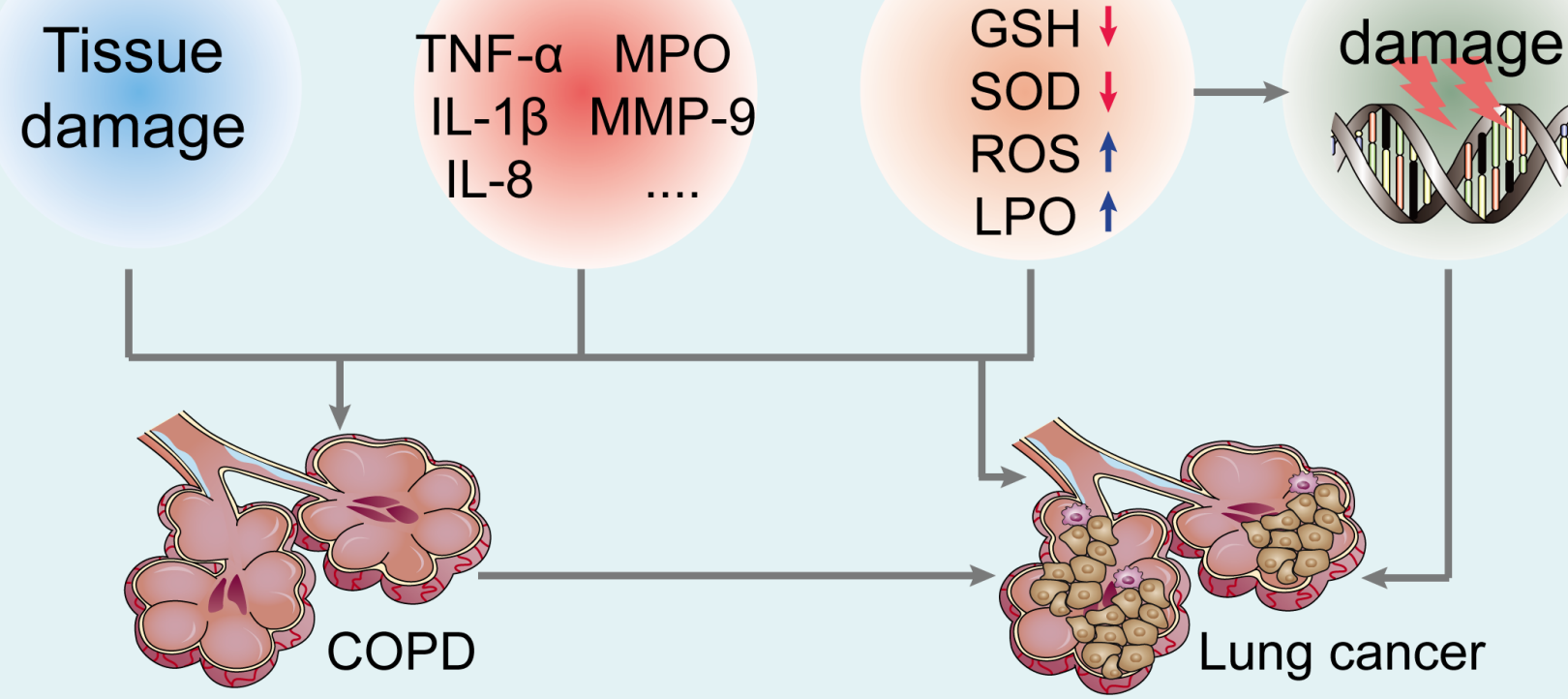

Figure 2: Effect of melatonin on the prevention of lung carcinogenesis. Melatonin inhibits urethane-induced lung carcinogenesis in mice. Moreover, melatonin attenuates cigarette smoke-induced lung tissue damage, inflammation, and oxidative stress. Melatonin may reduce the incidence of lung cancer and lung diseases (such as COPD, a key risk factor for lung cancer). TNF- $\alpha$, tumor necrosis factor- $\alpha$; IL-1 $\beta$, interleukin-1 $\beta$; MPO, myeloperoxidase; MMP-9, matrix metalloproteinase-9; GSH, glutathione; SOD, superoxide dismutase; ROS, reactive oxygen species; LPO, lipid peroxidation; COPD, chronic obstructive pulmonary diseases. 
treatment dose- and time- dependent decreased the viability of human A549 and PC9 lung adenocarcinoma cells, and increased their apoptotic index. Furthermore, melatonin treatment significantly upregulated the expression of $\mathrm{Bcl}-2$ associated $\mathrm{X}$ protein (Bax), p53 upregulated modulator of apoptosis (PUMA) and ROS, enhanced the caspase 3 activity, and downregulated the B-cell lymphoma-2 (Bcl-2) and GSH levels via the inhibition of histone deacetylase-1 (HDAC1) signaling pathway in adenocarcinoma cells [14] (Figure 3A). Moreover, Plaimee et al. $[15,30]$ have demonstrated that melatonin induces apoptosis in SK-LU-1 human lung adenocarcinoma cells. In combination with cisplatin, melatonin can potentiates cisplatin-induced apoptosis and cell cycle arrest in the $\mathrm{S}$ phase [5]. Thus, it is evident that melatonin can induce NSCLC cell apoptosis, making it potentially useful as an NSCLC treatment especially in combination with chemotherapeutic agents $[74,75]$.

\section{EFFECT OF MELATONIN ON NSCLC CELL PROLIFERATION}

Arguably the most fundamental trait of cancer cells involves their ability to sustain chronic proliferation [73]. Previous studies have reported that melatonin suppresses the proliferation of several cancer cells and can be viewed as an anti-mitogen $[14,89,90]$. Proliferating-cell nuclear antigen (PCNA) is a molecular marker for proliferation because of its role in cell division; the inhibition of PCNA is considered to be a viable anticancer strategy [91]. Our recent study demonstrated that melatonin supplementation downregulated PCNA expression and reduced the viability in both lung cancer A549 and PC9 cells [14]. In SKLU-1 cells, melatonin treatment reduced the intensity of nucleic acid/DNA [15]. When SK-LU-1 cells were co-cultured with human peripheral blood mononuclear cells (PBMC), it induced the cell cycle arrest in the G0/ G1 phase; this may be also related to the enhancement of immunomodulatory effect of melatonin [30] (Figure 3B). Considering the data discussed, it is likely that the anti-proliferative actions of melatonin may be related to its anticancer activity.

\section{EFFECT OF MELATONIN ON NSCLC CELL METASTASIS}

Greater than $90 \%$ of cancer-related mortalities result from metastases [92, 93]. Lung cancer cells metastasize to brain, bone, contra-lateral lung, liver and kidney, and metastatic growths are major cause of cancer-related mortality in men and women worldwide [94, 95]. Metastatic lesions are manifested in multiple steps, including localized invasion and intravasation at the primary tumor site, sustained survival in circulation, extravasation at distant organ site and colonization at the new site [93, 96]. Several reports have suggested that melatonin inhibits NSCLC metastasis. In the pinealectomized mice bearing Lewis lung carcinoma, melatonin treatment leads to significant decrement of in metastatic volume [32]. Furthermore, Zhou et al. [29] reported that Melatonin significantly inhibits the migration of A549 cells; this may be associated with the downregulation of the expression of osteopontin (OPN), myosin light chain kinase (MLCK), phosphorylation of myosin light chain (MLC), and up-regulation of the expression of occludin via the inhibition of c-jun-N-terminal kinases (JNK) signaling pathway (Figure 3C). Accordingly, melatonin has the potential to reduce the malignancy of NSCLC through the inhibition of cancer cells metastasis and progression. This would be consistent with a large number of reports showing that melatonin inhibits the epithelial-to-mesenchymal transition and metastases of a variety of cancer cell types $[17,97,98]$. Rho-associated kinase and its isoforms (ROCK-1 and ROCK-2) promote cancer invasion and migration by regulating actin rearrangements in the cytoskeleton [99]. A recent study by Borin et al. [17] reported that melatonin was effective in controlling metastatic breast cancer in vitro and in vivo, not only via suppression of the proliferation of cancer cells but also through suppression of cancer metastasis by ROCK-1 inhibition. Whether melatonin treatment inhibits NSCLC metastasis through antagonism of the ROCK pathway warrants further investigation.

\section{EFFECT OF MELATONIN ON IMMUNOMODULATION OF NSCLC}

Correlation of immune system with cancer is a dynamic and complex process, which involves their reciprocally modulation of each other $[61,100]$. The major component of anticancer immunity involves of both adaptive and innate immune responses, including the involvement of tumor antigen-specific cytotoxic $\mathrm{T}$ (CTL) and $\mathrm{T}$ effector $\left(\mathrm{T}_{\text {eff }}\right)$ cells, B cells, macrophages, natural killer $(\mathrm{NK})$ cells, and NK-T cells, etc. [100, 101]. Accordingly, strengthening anticancer immunity is considered an effective means of promoting cancer regression [102, 103].

Melatonin plays an important role in the immune system $[104,105]$. Circulating melatonin decreases with age coinciding with the age-related decline of immune system, which is referred to as immunosenescence, contributing to an increased susceptibility to infectious diseases, autoimmunity and cancer [106, 107]. Supplementation with melatonin prevents or delays the functional deterioration of immune system during aging [107]. Melatonin treatment prevents glucocorticoidinduced [108, 109] or age-related thymocytes apoptosis $[110,111]$; also, melatonin restores the degenerated thymus by increasing thymus weight and the total number of thymocytes $[110,112]$. Moreover, melatonin treatment 


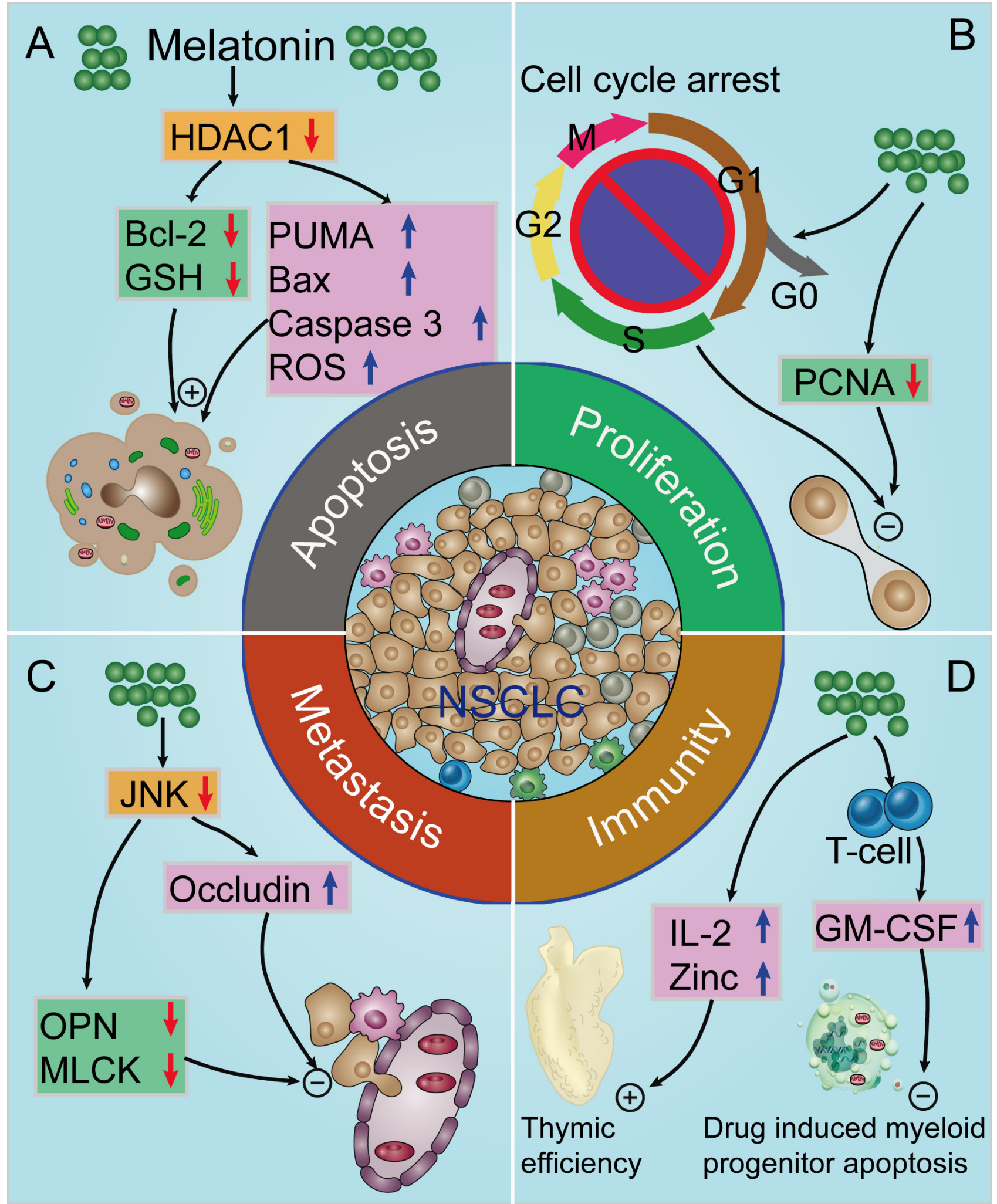

Figure 3: Proposed oncostatic actions of melatonin on the hallmarks of NSCLC. A. Melatonin treatment induces NSCLC cells apoptosis; B. melatonin inhibits NSCLC cell proliferation; C. melatonin supplementation suppresses NSCLC cells metastasis; D. melatonin has indirect anti-cancer effects via enhancement of immunomodulatory activity. HDAC1, histone deacetylase-1; Bcl-2, B-cell lymphoma-2; GSH, glutathione; PUMA, p53 up-regulated modulator of apoptosis; Bax, Bcl-2 associated X protein; ROS, reactive oxygen species; PCNA, proliferating-cell nuclear antigen; OPN, osteopontin; MLCK, myosin light chain kinase; IL-2, interleukin-2; GM-CSF, granulocyte-macrophage colony-stimulating factor. 
also stimulates the production of natural killer (NK) cells and macrophage/monocyte lineage cells in both the marrow and the spleen [107, 113-115]. The elevated NK cell number and function induced by melatonin are attributed partly to the cytokines produced by melatoninstimulated T-helper cells, including IL-2, IL-6, IL-12, and IFN- $\gamma[105,115]$.
Mounting evidence indicates that melatonin modulates cancer immunity to inhibit the development of NSCLC. Melatonin induced cytokine production has been shown in human PBMC for IL-1, IL-2, IL-6, IL12 and IFN- $\gamma$ [116-119]. When SK-LU-1 cells were co-cultured with PBMC, Plaimee and colleagues [30] reported that an indirect effect is exhibited at lower doses

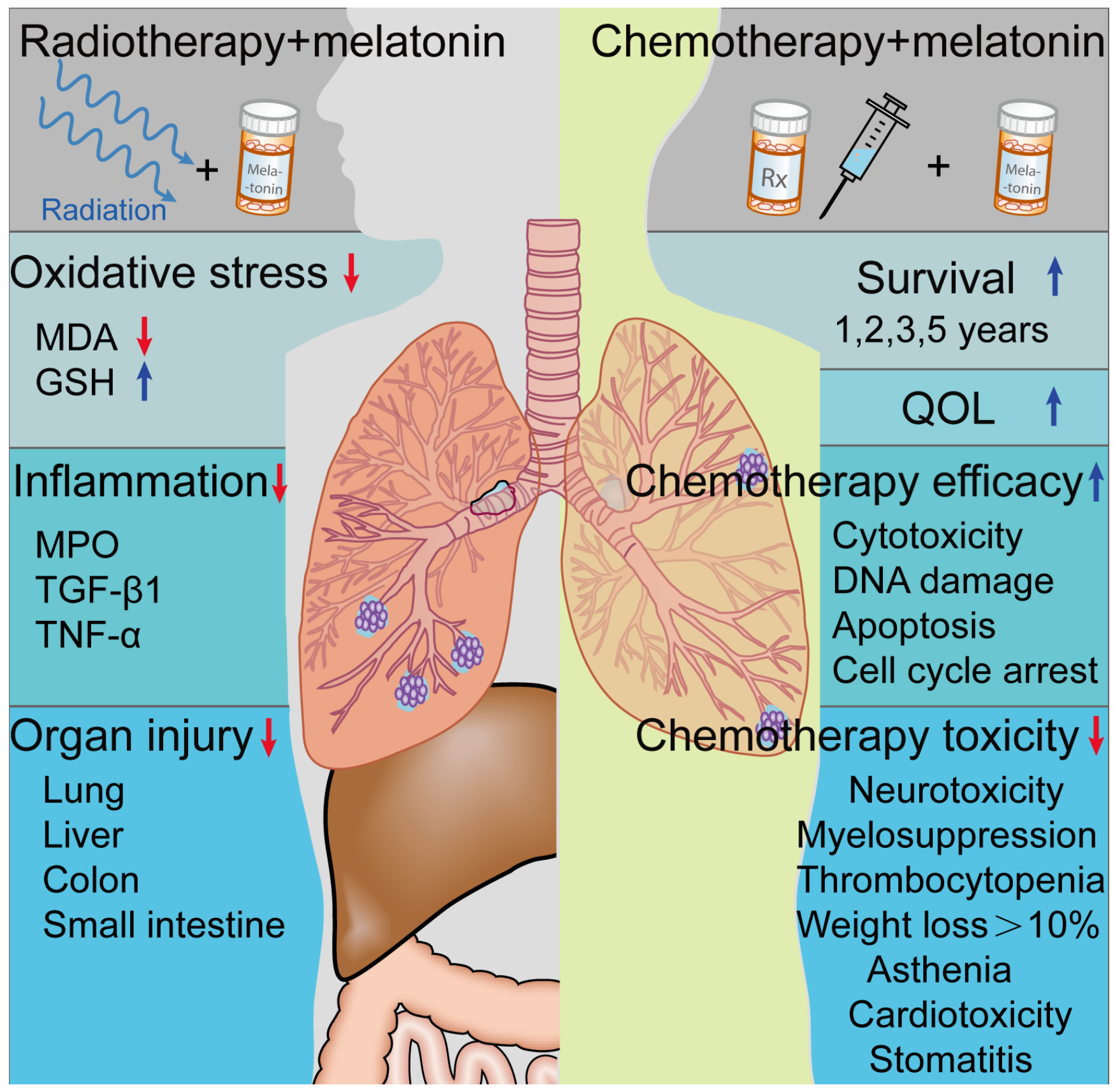

Figure 4: Effect of melatonin on radio- or chemotherapy. Melatonin treatment reduces radiation-induced lung injury in animal studies. Moreover, melatonin supplementation may significantly promotes the efficacy of chemotherapy, reduces chemotherapy toxicity, and improves the survival and quality of life (QOL) of NSCLC patients. MPO, myeloperoxidase; MDA, malondialdehyde; TGF- $\beta 1$, transforming growth factor- $\beta 1$; TNF- $\alpha$, tumor necrosis factor- $\alpha$; GSH, glutathione. 
of melatonin, enhancing human PBMC to counteract proliferation, increase apoptosis and oxidative stress in cancer cells. Moreover, Mocchegiani et al. [32] observed that melatonin due to its immunoenhancing properties decreased Lewis lung carcinoma metastasis in mice, with consequent restoration of thymic efficiency and increment of IL-2 production. Furthermore, in Lewis lung carcinoma bearing mice, melatonin rescued myeloid progenitor cells from chemotherapy induced apoptosis via a mechanism involving the endogenous production of granulocytemacrophage colony-stimulating factor (GM-CSF), which is produced by melatonin-stimulated bone marrow $\mathrm{T}$ cells [114] (Figure 3D). Collectively, these results imply that melatonin may have an indirect anticancer effect on NSCLC cells by enhancing of immunomodulation.

\section{DRUG SYNERGY OF MELATONIN WITH CHEMOTHERAPY}

Melatonin is an endogenous substance with low toxicity and favorable compatibility [61]. In human volunteers, oral administration of melatonin in doses of $1-300 \mathrm{mg}$ or 1 gram of melatonin daily for 30 days resulted in no observable negative side effects $[120,121]$. Combination studies of melatonin and chemotherapy have been reported to enhance the efficacy of drug against NSCLC cells and reduce the adverse therapeutic side effects $[5,30,122,123]$ (see Table. 2). In experimental studies, Kontek et al. [122] observed that the combination of melatonin and irinotecan increases the amount of DNA damage in A549 cells, but was not effective in inducing DNA damage in healthy human lymphocytes. Furthermore, melatonin supplementation rescued myeloid progenitor cells from chemotherapy-induced apoptosis [114]. Moreover, melatonin plus cisplatin or doxorubicin enhanced the cytotoxicity of chemotherapy against lung adenocarcinoma cells [5, 124]. Berberine, a plantderived agent, also exhibits anticancer effects. Lu et al. [125] reported that treatment with melatonin effectively increased berberine-induced apoptosis, and enhanced the berberine-mediated inhibition of cell proliferation, colony formation and cell migration in H1299 and A549 cells.

The existence of cancer-related immunosuppression has been demonstrated in several experimental and clinical observation [126, 127]. Melatonin stimulated IL-2 production via activating specific melatonin receptors expressed by TH1-lymphocytes [106]. In small clinical trials, Lissoni et al. [127] reported that the combination treatment of melatonin with IL-2 further promotes tumor regressions and improve 3-year survival in advanced NSCLC patients. Moreover, melatonin significantly enhanced the efficacy of the standard anticancer chemotherapies (cisplatin and etoposide), and improved the 1-, 2-, and 5-year survival in untreated metastatic NSCLC patients $[8,33,128,129]$. Additionally, melatonin supplementation also improved quality of life (QOL) in patients suffering with NSCLC [130], and reduced chemotherapy related toxicity, including neurotoxicity, thrombocytopenia, myelosuppression, asthenia, cardiotoxicity, stomatitis, and weight loss by greater than $10 \%$; however, melatonin did not limit alopecia or anemia $[8,33,128,129,131]$ (Figure 4). However, Egidio et al. [132] suggested that $20 \mathrm{mg}$ melatonin given orally at night did not improve appetite, weight, or QOL compared with placebo after studying 48 patients with advanced lung or gastrointestinal cancer. Although the outcome of current studies are inconsistent relative to the efficacy of melatonin treatment for advanced NSCLC, a large scale NSCLC patient sample given melatonin could yield important findings.

Although the use of EGFR tyrosine kinase inhibitors (TKIs), such as gefitinib and erlotinib, to treat advanced NSCLC patients has become a standard of care, the use of TKIs in NSCLC patients with T790M EGFR mutations causes drug resistance $[133,134]$. The most common mechanism to explain the resistance seen in EGFR mutation patients is the development of a secondary point mutation in the EGFR active domain, substituting a bulky methionine amino acid for threonine (T790M) [135]. Currently, the $7790 \mathrm{M}$ mutation is estimated to represent $50-60 \%$ of resistance to the first and second generation EGFR mutation TKIs [136]. Recent work by Yun et al. [133] reported that co-treatment of gefitinib with melatonin effectively decreased the viability, downregulated EGFR phosphorylation, and induced apoptosis in H1975 cells with T790M somatic mutation. These findings indicate that melatonin plus gefitinib may be an effective treatment for NSCLC with EGFR mutations resistant to TKImonotherapy; clinical trials should be carried out to test these combination therapy. Moreover, whether melatonin enhances the efficacy of targeted therapy in NSCLC also warrants further investigation.

\section{MELATONIN AND RADIOTHERAPY}

Conventionally, fractionated radiotherapy for NSCLC consists of 1.8-2.0 Gy fractions given once daily for 5 days each week for a total dose of 60 Gy or more [137]. This treatment strategy is associated with improved locoregional control and survival. This treatment, however, also causes radiation-induced lung toxicity, including pneumonitis and pulmonary fibrosis [138]. It has long been recognized that the damaging effects of ionizing radiation are brought about by both direct (DNA damage) and indirect (production of highly reactive free radicals) mechanisms [120]. In 1993, the initial evidence was provided related to the protective effects of melatonin against electromagnetic radiation by ultraviolet light [139]; thereafter, numerous papers have documented that melatonin is an effective agent against radiation-induced tissue damages [120, 140-142].

Several animal studies suggested that melatonin 
Table 2:The drug synergy of melatonin in NSCLC

\begin{tabular}{|c|c|c|c|c|}
\hline Cancer categories & $\begin{array}{l}\text { Number of } \\
\text { patients }\end{array}$ & Drugs and dose & Outcome & References \\
\hline \multicolumn{5}{|l|}{ Experimental studies } \\
\hline $\begin{array}{l}\text { SK-LU-1 NSCLC } \\
\text { cell line }\end{array}$ & None & $\begin{array}{l}\text { Melatonin }(1,2 \mathrm{mM})+ \\
\text { cisplatin }(10-200 \mu \mathrm{M}) \\
(48 \mathrm{~h} \text { in culture })\end{array}$ & $\begin{array}{l}\text { In the drug combination, } 1 \text { and } 2 \mathrm{mM} \\
\text { melatonin reduced IC } \mathrm{IC}_{50} \text { concentration of } \\
\text { cisplatin alone from } 50 \mu \mathrm{M} \text { to } 11 \text { and } 4 \mu \mathrm{M} \text {. } \\
\text { Thus, melatonin enhances cisplatin-induced } \\
\text { cytotoxicity and apoptosis in SK-LU-1 cells } \\
\text { and induces cell cycle arrest in the S phase } \\
\text { in contrast to cisplatin alone group }\end{array}$ & $\begin{array}{l}\text { Plaimee et } \\
\text { al. [5] }\end{array}$ \\
\hline $\begin{array}{l}\text { A549 cells and } \\
\text { healthy human } \\
\text { lymphocytes }\end{array}$ & None & $\begin{array}{l}\text { Melatonin }(50 \mu \mathrm{M})+ \\
\text { irinotecan }(7.5,15,30 \\
\text { and } 60 \mu \mathrm{M})\end{array}$ & $\begin{array}{l}\text { The combination treatment resulted in an } \\
\text { increase in the amount of DNA damage in } \\
\text { A549 cells, but was not effective in inducing } \\
\text { DNA damage in healthy human lymphocytes }\end{array}$ & $\begin{array}{l}\text { Kontek et } \\
\text { al. }[122]\end{array}$ \\
\hline A549 cells & None & $\begin{array}{l}\text { Melatonin }(0.1,1 \mathrm{mM}) \\
+ \text { doxorubicin }(0.1,1 \\
\text { microg/ml })\end{array}$ & $\begin{array}{l}\text { Melatonin intensified cytotoxicity of } \\
\text { doxorubicin in all cell lines, significantly } \\
\text { decreasing cell numbers and promoting } \\
\text { apoptosis }\end{array}$ & $\begin{array}{l}\text { Fic et al. } \\
{[124]}\end{array}$ \\
\hline $\begin{array}{l}\text { Female } \mathrm{C} 57 \mathrm{~B} / 6 \text { mice } \\
\text { with subcutaneous } \\
\text { propagation of Lewis } \\
\text { lung carcinoma }\end{array}$ & None & $\begin{array}{l}\text { Melatonin }(1 \mathrm{mg} / \mathrm{kg})+ \\
\text { cyclophosphamide }(40, \\
160 \mathrm{mg} / \mathrm{kg})+ \text { etoposide } \\
(20,40 \mathrm{mg} / \mathrm{kg})\end{array}$ & $\begin{array}{l}\text { Melatonin can rescue myeloid progenitor } \\
\text { cells from chemotherapy-induced apoptosis } \\
\text { via a mechanism involving the endogenous } \\
\text { production of GM-CSF by T cells }\end{array}$ & $\begin{array}{l}\text { Maestroni } \\
\text { et al. }[114]\end{array}$ \\
\hline $\begin{array}{l}\text { H1299 and A549 } \\
\text { cells }\end{array}$ & None & $\begin{array}{l}\text { Melatonin }(1 \mathrm{mM})+ \\
\text { berberine }(20 \mu \mathrm{M} \text { to } 200 \\
\mu \mathrm{M})\end{array}$ & $\begin{array}{l}\text { Melatonin sensitized NSCLC cells to } \\
\text { berberine and enhanced the growth } \\
\text { inhibitory effect of berberine by activating } \\
\text { caspase/Cyto C and inhibiting AP-2 } \beta / \\
\text { hTERT, NF- } \mathrm{B} / \mathrm{COX}-2 \text { and Akt/ERK } \\
\text { signaling pathways }\end{array}$ & $\begin{array}{l}\mathrm{Lu} \text { et al. } \\
{[125]}\end{array}$ \\
\hline \multicolumn{5}{|l|}{ Clinical trials } \\
\hline $\begin{array}{l}\text { Untreatable } \\
\text { metastatic NSCLC or } \\
\text { GI cancers }\end{array}$ & 846 & $\begin{array}{l}\text { Melatonin (20 mg/day) } \\
+ \text { IL-2 (3 million IU/day, } \\
5 \text { days/week, } 4 \text { weeks })+ \\
\text { supportive care }\end{array}$ & $\begin{array}{l}\text { The combination treatment provided a } \\
\text { further improvement in the percentage of } \\
\text { tumor regressions and of } 3 \text {-year survival } \\
\text { with respect to melatonin or supportive care } \\
\text { alone }\end{array}$ & $\begin{array}{l}\text { Lissoni et } \\
\text { al. [127] }\end{array}$ \\
\hline $\begin{array}{l}\text { Advanced lung } \\
\text { adenocarcinoma }\end{array}$ & 23 & $\begin{array}{l}\text { Melatonin }(20 \mathrm{mg} / \mathrm{day}) \\
+ \text { somatostatin }(1-3 \mathrm{mg} / \\
\text { day }+ \text { Retinoids }(5 \mathrm{ml})+ \\
\text { Vitamin D }(0.3 \mathrm{mg} / \text { day }) \\
+ \text { bromocriptine }(2.5 \mathrm{mg} / \\
\text { day }+ \text { cyclophosphamide } \\
(150 \mathrm{mg} / \text { day })\end{array}$ & $\begin{array}{l}\text { Patients with combination treatment had a } \\
\text { median overall survival of } 95 \text { days, with very } \\
\text { modest toxic effects and an improvement } \\
\text { in both respiratory and general symptoms } \\
\text { associated with length of survival }\end{array}$ & $\begin{array}{l}\text { Norsa et al. } \\
{[123]}\end{array}$ \\
\hline $\begin{array}{l}\text { Untreated metastatic } \\
\text { NSCLC }\end{array}$ & 147 & $\begin{array}{l}\text { Melatonin }(20 \mathrm{mg} / \text { day })+ \\
\text { cisplatin plus etoposide } \\
\text { or gemcitabine }\end{array}$ & $\begin{array}{l}\text { The 2-year survival rate and the overall } \\
\text { tumor regression rate achieved in patients } \\
\text { concomitantly treated with melatonin was } \\
\text { significantly higher than that found in those } \\
\text { treated with chemotherapy alone }\end{array}$ & $\begin{array}{l}\text { Lissoni et } \\
\text { al. [33] }\end{array}$ \\
\hline $\begin{array}{l}\text { Untreated metastatic } \\
\text { NSCLC }\end{array}$ & 100 & $\begin{array}{l}\text { Melatonin }(20 \mathrm{mg} / \text { day })+ \\
\text { cisplatin }(20 \mathrm{mg} / \mathrm{m} 2 / \text { day }) \\
+ \text { etoposide }(100 \mathrm{mg} / \mathrm{m} 2 / \\
\text { day })\end{array}$ & $\begin{array}{l}\text { Overall tumor regression rate and the 5-year } \\
\text { survival results }(49 \%) \text { were significantly } \\
\text { higher in patients concomitantly treated with } \\
\text { melatonin. In particular, no patient treated } \\
\text { with chemotherapy alone was alive after } 2 \\
\text { years }\end{array}$ & $\begin{array}{l}\text { Lissoni et } \\
\text { al. [8] }\end{array}$ \\
\hline Advanced NSCLC & 70 & $\begin{array}{l}\text { Melatonin }(20 \mathrm{mg} / \text { day })+ \\
\text { cisplatin }(20 \mathrm{mg} / \mathrm{m} 2 / \text { day }) \\
+ \text { etoposide }(100 \mathrm{mg} / \mathrm{m} 2 / \\
\text { day })\end{array}$ & $\begin{array}{l}\text { The percent of 1-year survival was } \\
\text { significantly higher in patients treated with } \\
\text { melatonin plus chemotherapy than in those } \\
\text { who received chemotherapy alone }(15 / 34 \text { vs. } \\
7 / 36, \mathrm{P}<0.05)\end{array}$ & $\begin{array}{l}\text { Lissoni et } \\
\text { al. [129] }\end{array}$ \\
\hline
\end{tabular}

GM-CSF, granulocyte-macrophage colony-stimulating factor; Cyto C, cytochrome C; AP-2 $\beta$, activator protein 2 $\beta$; hTERT, telomerase reverses transcriptase; NF- $\mathrm{B}$, nuclear factor $\kappa \mathrm{B}$; COX-2, cyclooxygenase 2; ERK, extracellular signal-regulated kinase 
treatment can reduce ionizing radiation-induced lung injuries [7, 143, 144]. When the thoracic regions of rats were irradiated (18 Gy), melatonin administration inhibited lipid peroxidation and radiation-induced lung injury [144]. Furthermore, Jang et al. [143] reported that melatonin reduced radiation (12 Gy)-induced lung injury in mice a shown by significant reduction in oxidative stress and of the production of cytokines, including TGF- $\beta 1$ and TNF- $\alpha$. Moreover, Sener and colleagues [7] reported that melatonin reduced damage to the lung, liver, colon and ileum, after whole body irradiation (800 cGy) to rats (Figure 4) and Vijuyalaxmi and co-workers [145] found that melatonin preserved the survival of mice exposed to a lethal dose of ionizing radiation (815 cGy). In sum, results suggest that supplementing cancer patients with adjuvant therapy of melatonin may alleviate the symptoms due to radiation-induced organ injury. Additionally, the efficacy of melatonin in combination with radiotherapy should be tested in NSCLC patients.

\section{POTENTIAL DIRECTIONS}

Research related to the anticancer actions of melatonin on NSCLC cells has made only minor progress. One aspect that should be further examined is the antiangiogenic actions of melatonin in NSCLC [27, 146]. Vascular endothelial growth factor (VEGF) is a highly active angiogenic factor, and the evidence of abnormally high blood VEGF levels has been proven to be associated with poor prognosis in cancer patients [147]. Lissoni et al. [31] reported that melatonin treatment reduces serum VEGF levels in advanced cancer patients (containing 8 NSCLC patients). Moreover, Dai et al. [148] suggested that melatonin suppresses endogenous VEGF expression in A549 cells. However, the mechanisms of melatonin's antiangiogenic in any tumor including NSCLC are still unclear. Numerous studies have documented that melatonin exhibits antiangiogenic actions, in part, by downregulating VEGF and HIF-1 $\alpha$ in several cancers via different mechanisms; the cancer types included breast $[16,149]$, prostate [150-152], colon [153, 154], liver [155], and pancreatic cancer $[156,157]$. These studies may provide reference for the future work in the NSCLC research field.

Fibroblasts are a component of the tumor microenvironment. Activated fibroblasts release mediators such as growth factors, cytokines and immune modulators [158]. Fibroblasts with this altered phenotype are termed cancer-associated fibroblasts (CAFs) which largely contribute to the establishment of a reactive tumor stoma that is permissive of even conductive to cancer cell survival [158, 159]. Kim et al. [160] suggested that melatonin suppresses acrolein-induced IL-8 production via extracellular signal-regulated kinases 1/2 (ERK1/2) and phosphatidylinositol 3-kinase (PI3K)/Akt signal inhibition in human pulmonary fibroblasts (HPFs). These results imply an correlation between melatonin and HPFs, but whether melatonin reduces the secretion of potent oncogenic molecules by CAFs, such as TGF- $\beta$ [161] and hepatocyte growth factor (HGF) [162], or inhibits other tumor microenvironment members, such as immune inflammatory cells and endothelial cells [163], should be investigated.

In breast or colon cancer, evident experimental studies have confirmed a correlation between the disruption of the melatonin rhythm and cancer [164, 165]. Although the epidemiologic surveys suggest that men who worked at night at anytime have a higher risk for lung cancer, with excesses apparent across all main histologic subtypes [50], additional evidence for this from experimental studies is urgently needed. While the anticancer mechanisms of melatonin in breast cancer has been extensively explored [87, 97, 166], the antilung cancer actions of melatonin have been generally overlooked.

\section{CONCLUDING REMARKS}

Melatonin may be a potential anticancer drug in the treatment of NSCLC as well as other cancer types. Since melatonin treatment enhances the efficacy and reduces the side-effects of radio- or chemotherapies, and its exogenous supplementation may allow for the use of larger amounts of conventional treatments thereby exaggerating their effectiveness as anticancer treatments. Furthermore, melatonin, via its anti-proliferative, proapoptotic, anti-metastatic, and immunostimulatory actions, should be given more consideration as an effective oncostatic agent. Inasmuch as melatonin has low toxicity and highly favorable compatibility, further clinical trials which include melatonin and the clarification of additional molecular processes of melatonin's oncostatic effects will help to facilitate better applications of melatonin in the area of NSCLC treatment.

\section{ACKNOWLEDGEMENTS}

This work was supported by National Natural Science Foundation of China (81500263), China Postdoctoral Science Foundation (2015M572681), and the Excellent Doctoral Support Project of the Fourth Military Medical University (2015D02).

\section{CONFLICTS OF INTEREST}

There is no conflict of interest.

\section{REFERENCES}

1. Torre LA, Bray F, Siegel RL, Ferlay J, Lortet-Tieulent J, Jemal A. Global cancer statistics, 2012. CA Cancer J Clin. 
2015; 65:87-108.

2. Bender E. Epidemiology: The dominant malignancy. Nature. 2014; 513:S2-3.

3. Ettinger DS, Akerley W, Borghaei H, Chang AC, Cheney RT, Chirieac LR, D’Amico TA, Demmy TL, Govindan R, Grannis FW, Jr., Grant SC, Horn L, Jahan TM, Komaki R, Kong FM, Kris MG, et al. Non-small cell lung cancer, version 2.2013. J Natl Compr Canc Netw. 2013; 11:645653; quiz 653.

4. Johnson DH, Schiller JH, Bunn PA, Jr. Recent clinical advances in lung cancer management. J Clin Oncol. 2014; 32:973-982.

5. Plaimee P, Weerapreeyakul N, Barusrux S, Johns NP. Melatonin potentiates cisplatin-induced apoptosis and cell cycle arrest in human lung adenocarcinoma cells. Cell Prolif. 2015; 48:67-77.

6. Kim W, Jeong JW, Kim JE. CCAR2 deficiency augments genotoxic stress-induced apoptosis in the presence of melatonin in non-small cell lung cancer cells. Tumour Biol. 2014; 35:10919-10929.

7. Sener G, Jahovic N, Tosun O, Atasoy BM, Yegen BC. Melatonin ameliorates ionizing radiation-induced oxidative organ damage in rats. Life Sci. 2003; 74:563-572.

8. Lissoni P, Chilelli M, Villa S, Cerizza L, Tancini G. Five years survival in metastatic non-small cell lung cancer patients treated with chemotherapy alone or chemotherapy and melatonin: a randomized trial. J Pineal Res. 2003; 35:12-15.

9. Reiter RJ, Tan DX, Fuentes-Broto L. Melatonin: a multitasking molecule. Prog Brain Res. 2010; 181:127-151.

10. Gobbo MG, Dizeyi N, Abrahamsson PA, Bertilsson PA, Masiteli VS, Pytlowanciv EZ, Taboga SR, Goes RM. Influence of Melatonin on the Proliferative and Apoptotic Responses of the Prostate under Normal and Hyperglycemic Conditions. J Diabetes Res. 2015; 2015:538529.

11. Tan DX, Manchester LC, Esteban-Zubero E, Zhou Z, Reiter RJ. Melatonin as a Potent and Inducible Endogenous Antioxidant: Synthesis and Metabolism. Molecules. 2015; 20:18886-18906.

12. Reiter RJ, Tan DX, Manchester LC, Qi W. Biochemical reactivity of melatonin with reactive oxygen and nitrogen species: a review of the evidence. Cell Biochem Biophys. 2001; 34:237-256.

13. Manchester LC, Coto-Montes A, Boga JA, Andersen LP, Zhou Z, Galano A, Vriend J, Tan DX, Reiter RJ. Melatonin: an ancient molecule that makes oxygen metabolically tolerable. J Pineal Res. 2015; 59:403-419.

14. Fan C, Pan Y, Yang Y, Di S, Jiang S, Ma Z, Li T, Zhang Z, Li W, Li X, Reiter RJ, Yan X. HDAC1 inhibition by melatonin leads to suppression of lung adenocarcinoma cells via induction of oxidative stress and activation of apoptotic pathways. J Pineal Res. 2015; 59:321-333.

15. Plaimee P, Weerapreeyakul N, Thumanu K, Tanthanuch W, Barusrux S. Melatonin induces apoptosis through biomolecular changes, in SK-LU-1 human lung adenocarcinoma cells. Cell Prolif. 2014; 47:564-577.

16. Alvarez-Garcia V, Gonzalez A, Alonso-Gonzalez C, Martinez-Campa C, Cos S. Regulation of vascular endothelial growth factor by melatonin in human breast cancer cells. J Pineal Res. 2013; 54:373-380.

17. Borin TF, Arbab AS, Gelaleti GB, Ferreira LC, Moschetta MG, Jardim-Perassi BV, Iskander A, Varma NR, Shankar A, Coimbra VB, Fabri VA, de Oliveira JG, Zuccari DA. Melatonin decreases breast cancer metastasis by modulating Rho-associated kinase protein-1 expression. J Pineal Res. 2016; 60:3-15.

18. Woo SM, Min KJ, Kwon TK. Melatonin-mediated Bim upregulation and cyclooxygenase-2 (COX-2) down-regulation enhances tunicamycin-induced apoptosis in MDA-MB-231 cells. J Pineal Res. 2015; 58:310-320.

19. Alonso-Gonzalez C, Gonzalez A, Martinez-Campa C, Gomez-Arozamena J, Cos S. Melatonin sensitizes human breast cancer cells to ionizing radiation by downregulating proteins involved in double-strand DNA break repair. J Pineal Res. 2015; 58:189-197.

20. Proietti S, Cucina A, Dobrowolny G, D'Anselmi F, Dinicola S, Masiello MG, Pasqualato A, Palombo A, Morini V, Reiter RJ, Bizzarri M. Melatonin down-regulates MDM2 gene expression and enhances p53 acetylation in MCF-7 cells. J Pineal Res. 2014; 57:120-129.

21. Hevia D, Gonzalez-Menendez P, Quiros-Gonzalez I, Miar A, Rodriguez-Garcia A, Tan DX, Reiter RJ, Mayo JC, Sainz RM. Melatonin uptake through glucose transporters: a new target for melatonin inhibition of cancer. J Pineal Res. 2015; 58:234-250.

22. Paroni R, Terraneo L, Bonomini F, Finati E, Virgili E, Bianciardi P, Favero G, Fraschini F, Reiter RJ, Rezzani R, Samaja M. Antitumour activity of melatonin in a mouse model of human prostate cancer: relationship with hypoxia signalling. J Pineal Res. 2014; 57:43-52.

23. Shiu SY, Leung WY, Tam CW, Liu VW, Yao KM. Melatonin MT1 receptor-induced transcriptional upregulation of $\mathrm{p} 27(\mathrm{Kip} 1)$ in prostate cancer antiproliferation is mediated via inhibition of constitutively active nuclear factor kappa B (NF-kappaB): potential implications on prostate cancer chemoprevention and therapy. J Pineal Res. 2013; 54:69-79.

24. Joo SS, Yoo YM. Melatonin induces apoptotic death in LNCaP cells via p38 and JNK pathways: therapeutic implications for prostate cancer. J Pineal Res. 2009; 47:814.

25. Ordonez R, Fernandez A, Prieto-Dominguez N, Martinez L, Garcia-Ruiz C, Fernandez-Checa JC, Mauriz JL, GonzalezGallego J. Ceramide metabolism regulates autophagy and apoptotic cell death induced by melatonin in liver cancer cells. J Pineal Res. 2015; 59:178-189.

26. Ordonez R, Carbajo-Pescador S, Prieto-Dominguez N, Garcia-Palomo A, Gonzalez-Gallego J, Mauriz JL. 
Inhibition of matrix metalloproteinase-9 and nuclear factor kappa B contribute to melatonin prevention of motility and invasiveness in HepG2 liver cancer cells. J Pineal Res. 2014; 56:20-30.

27. Leon J, Casado J, Jimenez Ruiz SM, Zurita MS, GonzalezPuga C, Rejon JD, Gila A, Munoz de Rueda P, Pavon EJ, Reiter RJ, Ruiz-Extremera A, Salmeron J. Melatonin reduces endothelin-1 expression and secretion in colon cancer cells through the inactivation of FoxO-1 and NFkappabeta. J Pineal Res. 2014; 56:415-426.

28. Hong Y, Won J, Lee Y, Lee S, Park K, Chang KT, Hong $\mathrm{Y}$. Melatonin treatment induces interplay of apoptosis, autophagy, and senescence in human colorectal cancer cells. J Pineal Res. 2014; 56:264-274.

29. Zhou Q, Gui S, Zhou Q, Wang Y. Melatonin inhibits the migration of human lung adenocarcinoma A549 cell lines involving JNK/MAPK pathway. PLoS One. 2014; 9:e101132.

30. Plaimee P, Khamphio M, Weerapreeyakul N, Barusrux S, Johns NP. Immunomodulatory effect of melatonin in SKLU-1 human lung adenocarcinoma cells co-cultured with peripheral blood mononuclear cells. Cell Prolif. 2014; 47:406-415.

31. Lissoni P, Rovelli F, Malugani F, Bucovec R, Conti A, Maestroni GJ. Anti-angiogenic activity of melatonin in advanced cancer patients. Neuro Endocrinol Lett. 2001; 22:45-47.

32. Mocchegiani E, Perissin L, Santarelli L, Tibaldi A, Zorzet S, Rapozzi V, Giacconi R, Bulian D, Giraldi T. Melatonin administration in tumor-bearing mice (intact and pinealectomized) in relation to stress, zinc, thymulin and IL-2. Int J Immunopharmacol. 1999; 21:27-46.

33. Lissoni P. Biochemotherapy with standard chemotherapies plus the pineal hormone melatonin in the treatment of advanced solid neoplasms. Pathol Biol (Paris). 2007; 55:201-204.

34. Reiter RJ. Melatonin: the chemical expression of darkness. Mol Cell Endocrinol. 1991; 79(1-3):C153-158.

35. Hardeland R, Madrid JA, Tan DX, Reiter RJ. Melatonin, the circadian multioscillator system and health: the need for detailed analyses of peripheral melatonin signaling. J Pineal Res. 2012; 52:139-166.

36. Eisenstein M. Chronobiology: stepping out of time. Nature. 2013; 497:S10-12.

37. de Bodinat C, Guardiola-Lemaitre B, Mocaer E, Renard P, Munoz C, Millan MJ. Agomelatine, the first melatonergic antidepressant: discovery, characterization and development. Nat Rev Drug Discov. 2010; 9:628-642.

38. Stevens RG, Brainard GC, Blask DE, Lockley SW, Motta ME. Breast cancer and circadian disruption from electric lighting in the modern world. CA Cancer J Clin. 2014; 64:207-218.

39. Brainard GC, Hanifin JP, Greeson JM, Byrne B, Glickman G, Gerner E, Rollag MD. Action spectrum for melatonin regulation in humans: evidence for a novel circadian photoreceptor. J Neurosci. 2001; 21:6405-6412.

40. Glickman G, Levin R, Brainard GC. Ocular input for human melatonin regulation: relevance to breast cancer. Neuro Endocrinol Lett. 2002; 23 Suppl 2:17-22.

41. Gaddy JR, Rollag MD, Brainard GC. Pupil size regulation of threshold of light-induced melatonin suppression. J Clin Endocrinol Metab. 1993; 77:1398-1401.

42. Brainard GC, Rollag MD, Hanifin JP. Photic regulation of melatonin in humans: ocular and neural signal transduction. J Biol Rhythms. 1997; 12:537-546.

43. Gooley JJ, Chamberlain K, Smith KA, Khalsa SB, Rajaratnam SM, Van Reen E, Zeitzer JM, Czeisler CA, Lockley SW. Exposure to room light before bedtime suppresses melatonin onset and shortens melatonin duration in humans. J Clin Endocrinol Metab. 2011; 96:E463-472.

44. Zeitzer JM, Dijk DJ, Kronauer R, Brown E, Czeisler C. Sensitivity of the human circadian pacemaker to nocturnal light: melatonin phase resetting and suppression. J Physiol. 2000; 526 Pt 3:695-702.

45. Reiter RJ, Tan DX, Korkmaz A, Erren TC, Piekarski C, Tamura H, Manchester LC. Light at night, chronodisruption, melatonin suppression, and cancer risk: a review. Crit Rev Oncog. 2007; 13:303-328.

46. Jia Y, Lu Y, Wu K, Lin Q, Shen W, Zhu M, Huang S, Chen J. Does night work increase the risk of breast cancer? A systematic review and meta-analysis of epidemiological studies. Cancer Epidemiol. 2013; 37:197-206.

47. Papantoniou K, Castano-Vinyals G, Espinosa A, Aragones N, Perez-Gomez B, Ardanaz E, Altzibar JM, Sanchez VM, Gomez-Acebo I, Llorca J, Munoz D, Tardon A, Peiro R, Marcos-Gragera R, Pollan M, Kogevinas M. Breast cancer risk and night shift work in a case-control study in a Spanish population. Eur J Epidemiol. 2015.

48. Akerstedt T, Knutsson A, Narusyte J, Svedberg P, Kecklund G, Alexanderson K. Night work and breast cancer in women: a Swedish cohort study. BMJ Open. 2015; 5:e008127.

49. Papantoniou K, Castano-Vinyals G, Espinosa A, Aragones N, Perez-Gomez B, Burgos J, Gomez-Acebo I, Llorca J, Peiro R, Jimenez-Moleon JJ, Arredondo F, Tardon A, Pollan M, Kogevinas M. Night shift work, chronotype and prostate cancer risk in the MCC-Spain case-control study. Int J Cancer. 2015; 137:1147-1157.

50. Parent ME, El-Zein M, Rousseau MC, Pintos J, Siemiatycki J. Night work and the risk of cancer among men. Am J Epidemiol. 2012; 176:751-759.

51. Wang X, Ji A, Zhu Y, Liang Z, Wu J, Li S, Meng S, Zheng X, Xie L. A meta-analysis including dose-response relationship between night shift work and the risk of colorectal cancer. Oncotarget. 2015; 6:25046-25060. doi: 10.18632/oncotarget.4502.

52. Levin RD, Daehler MA, Grutsch JF, Quiton J, Lis CG, Peterson C, Gupta D, Watson K, Layer D, Huff-Adams 
S, Desai B, Sharma P, Wallam M, Delioukina M, Ball $\mathrm{P}$, Bryant $\mathrm{M}$, et al. Circadian function in patients with advanced non-small-cell lung cancer. Br J Cancer. 2005; 93:1202-1208.

53. Mazzoccoli G, Carughi S, De Cata A, La Viola M, Vendemiale G. Melatonin and cortisol serum levels in lung cancer patients at different stages of disease. Med Sci Monit. 2005; 11:Cr284-288.

54. $\mathrm{Hu} \mathrm{S}$, Shen $\mathrm{G}, \mathrm{Yin} \mathrm{S}, \mathrm{Xu} \mathrm{W}, \mathrm{Hu}$ B. Melatonin and tryptophan circadian profiles in patients with advanced nonsmall cell lung cancer. Adv Ther. 2009; 26:886-892.

55. Anisimov VN, Popovich IG, Zabezhinski MA, Anisimov SV, Vesnushkin GM, Vinogradova IA. Melatonin as antioxidant, geroprotector and anticarcinogen. Biochim Biophys Acta. 2006; 1757(5-6):573-589.

56. Shah PN, Mhatre MC, Kothari LS. Effect of melatonin on mammary carcinogenesis in intact and pinealectomized rats in varying photoperiods. Cancer Res. 1984; 44:3403-3407.

57. Kothari LS. Influence of chronic melatonin on 9,10-dimethyl-1,2-benzanthracene-induced mammary tumors in female Holtzman rats exposed to continuous light. Oncology. 1987; 44:64-66.

58. Lenoir V, de Jonage-Canonico MB, Perrin MH, Martin A, Scholler R, Kerdelhue B. Preventive and curative effect of melatonin on mammary carcinogenesis induced by dimethylbenz[a]anthracene in the female Sprague-Dawley rat. Breast Cancer Res. 2005; 7:R470-476.

59. Dakshayani KB, Subramanian P, Manivasagam T, Essa MM, Manoharan S. Melatonin modulates the oxidantantioxidant imbalance during N-nitrosodiethylamine induced hepatocarcinogenesis in rats. J Pharm Pharm Sci. 2005; 8:316-321.

60. Anisimov VN, Popovich IG, Zabezhinski MA. Melatonin and colon carcinogenesis: I. Inhibitory effect of melatonin on development of intestinal tumors induced by 1,2-dimethylhydrazine in rats. Carcinogenesis. 1997; 18:1549-1553.

61. Xin Z, Jiang S, Jiang P, Yan X, Fan C, Di S, Wu G, Yang Y, Reiter RJ, Ji G. Melatonin as a treatment for gastrointestinal cancer: a review. J Pineal Res. 2015; 58:375-387.

62. Anisimov VN, Zabezhinski MA, Popovich IG, Zaripova EA, Musatov SA, Andre V, Vigreux C, Godard T, Sichel F. Inhibitory effect of melatonin on 7, 12-dimethylbenz[a] anthracene-induced carcinogenesis of the uterine cervix and vagina in mice and mutagenesis in vitro. Cancer Lett. 2000; 156:199-205.

63. Vesnushkin GM, Plotnikova NA, Semenchenko AV, Anisimov VN. Melatonin inhibits urethane-induced carcinogenesis tumors in murine lung. Vopr Onkol. 2006; 52:164-168.

64. Biesalski HK, Bueno de Mesquita B, Chesson A, Chytil F, Grimble R, Hermus RJ, Kohrle J, Lotan R, Norpoth K, Pastorino U, Thurnham D. European Consensus Statement on Lung Cancer: risk factors and prevention. Lung Cancer
Panel. CA Cancer J Clin. 1998; 48:167-176; discussion 164-166.

65. Smith CJ, Hansch C. The relative toxicity of compounds in mainstream cigarette smoke condensate. Food Chem Toxicol. 2000; 38:637-646.

66. Stampfli MR, Anderson GP. How cigarette smoke skews immune responses to promote infection, lung disease and cancer. Nat Rev Immunol. 2009; 9:377-384.

67. Ozguner F, Koyu A, Cesur G. Active smoking causes oxidative stress and decreases blood melatonin levels. Toxicol Ind Health. 2005; 21(1-2):21-26.

68. El-Sokkary GH, Cuzzocrea S, Reiter RJ. Effect of chronic nicotine administration on the rat lung and liver: beneficial role of melatonin. Toxicology. 2007; 239(1-2):60-67.

69. Unlu M, Fidan F, Sezer M, Tetik L, Sahin O, Esme H, Koken T, Serteser M. Effects of melatonin on the oxidant/ antioxidant status and lung histopathology in rabbits exposed to cigarette smoke. Respirology. 2006; 11:422-428.

70. Sun CK, Lee FY, Kao YH, Chiang HJ, Sung PH, Tsai TH, Lin YC, Leu S, Wu YC, Lu HI, Chen YL, Chung SY, Su HL, Yip HK. Systemic combined melatonin-mitochondria treatment improves acute respiratory distress syndrome in the rat. J Pineal Res. 2015; 58:137-150.

71. Shin IS, Shin NR, Park JW, Jeon CM, Hong JM, Kwon OK, Kim JS, Lee IC, Kim JC, Oh SR, Ahn KS. Melatonin attenuates neutrophil inflammation and mucus secretion in cigarette smoke-induced chronic obstructive pulmonary diseases via the suppression of Erk-Sp1 signaling. J Pineal Res. 2015; 58:50-60.

72. Kawanishi S, Hiraku Y, Oikawa S. Mechanism of guaninespecific DNA damage by oxidative stress and its role in carcinogenesis and aging. Mutat Res. 2001; 488:65-76.

73. Hanahan D, Weinberg RA. Hallmarks of cancer: the next generation. Cell. 2011; 144:646-674.

74. Lowe SW, Lin AW. Apoptosis in cancer. Carcinogenesis. 2000; 21:485-495.

75. Pariente R, Pariente JA, Rodriguez AB, Espino J. Melatonin sensitizes human cervical cancer HeLa cells to cisplatininduced cytotoxicity and apoptosis: effects on oxidative stress and DNA fragmentation. J Pineal Res. 2016; 60:5564.

76. Leja-Szpak A, Jaworek J, Pierzchalski P, Reiter RJ. Melatonin induces pro-apoptotic signaling pathway in human pancreatic carcinoma cells (PANC-1). J Pineal Res. 2010; 49:248-255.

77. Park EJ, Woo SM, Min KJ, Kwon TK. Transcriptional and post-translational regulation of Bim controls apoptosis in melatonin-treated human renal cancer Caki cells. J Pineal Res. 2014; 56:97-106.

78. Garcia-Santos G, Antolin I, Herrera F, Martin V, RodriguezBlanco J, del Pilar Carrera M, Rodriguez C. Melatonin induces apoptosis in human neuroblastoma cancer cells. J Pineal Res. 2006; 41:130-135.

79. Bizzarri M, Proietti S, Cucina A, Reiter RJ. Molecular 
mechanisms of the pro-apoptotic actions of melatonin in cancer: a review. Expert Opin Ther Targets. 2013; 17:14831496.

80. Fernandez A, Ordonez R, Reiter RJ, Gonzalez-Gallego J, Mauriz JL. Melatonin and endoplasmic reticulum stress: relation to autophagy and apoptosis. J Pineal Res. 2015; 59:292-307.

81. Vriend J, Reiter RJ. Melatonin as a proteasome inhibitor. Is there any clinical evidence? Life Sci. 2014; 115(1-2):8-14.

82. Jaworek J, Leja-Szpak A. Melatonin influences pancreatic cancerogenesis. Histol Histopathol. 2014; 29:423-431.

83. Rodriguez C, Martin V, Herrera F, Garcia-Santos G, Rodriguez-Blanco J, Casado-Zapico S, Sanchez-Sanchez AM, Suarez S, Puente-Moncada N, Anitua MJ, Antolin I. Mechanisms involved in the pro-apoptotic effect of melatonin in cancer cells. Int J Mol Sci. 2013; 14:65976613.

84. Proietti S, Cucina A, Reiter RJ, Bizzarri M. Molecular mechanisms of melatonin's inhibitory actions on breast cancers. Cell Mol Life Sci. 2013; 70:2139-2157.

85. Sanchez-Hidalgo M, Guerrero JM, Villegas I, Packham $\mathrm{G}$, de la Lastra CA. Melatonin, a natural programmed cell death inducer in cancer. Curr Med Chem. 2012; 19:38053821 .

86. Lanoix D, Lacasse AA, Reiter RJ, Vaillancourt C. Melatonin: the smart killer: the human trophoblast as a model. Mol Cell Endocrinol. 2012; 348:1-11.

87. Mediavilla MD, Sanchez-Barcelo EJ, Tan DX, Manchester L, Reiter RJ. Basic mechanisms involved in the anti-cancer effects of melatonin. Curr Med Chem. 2010; 17:4462-4481.

88. Sainz RM, Mayo JC, Rodriguez C, Tan DX, Lopez-Burillo $\mathrm{S}$, Reiter RJ. Melatonin and cell death: differential actions on apoptosis in normal and cancer cells. Cell Mol Life Sci. 2003; 60:1407-1426.

89. Nasrabadi NN, Ataee R, Abediankenari S, Shokrzadeh M, Najafi M, Hoseini SV, Jan HH. Expression of MT2 receptor in patients with gastric adenocarcinoma and its relationship with clinicopathological features. J Gastrointest Cancer. 2014; 45:54-60.

90. Wang J, Xiao X, Zhang Y, Shi D, Chen W, Fu L, Liu L, Xie F, Kang T, Huang W, Deng W. Simultaneous modulation of COX-2, p300, Akt, and Apaf-1 signaling by melatonin to inhibit proliferation and induce apoptosis in breast cancer cells. J Pineal Res. 2012; 53:77-90.

91. Stoimenov I, Helleday T. PCNA on the crossroad of cancer. Biochem Soc Trans. 2009; 37(Pt 3):605-613.

92. Fidler IJ. The pathogenesis of cancer metastasis: the 'seed and soil' hypothesis revisited. Nat Rev Cancer. 2003; 3:453-458.

93. Nguyen DX, Bos PD, Massague J. Metastasis: from dissemination to organ-specific colonization. Nat Rev Cancer. 2009; 9:274-284.

94. Thakur RK, Yadav VK, Kumar A, Singh A, Pal K, Hoeppner L, Saha D, Purohit G, Basundra R, Kar A, Halder
R, Kumar P, Baral A, Kumar MJ, Baldi A, Vincenzi B, et al. Non-metastatic 2 (NME2)-mediated suppression of lung cancer metastasis involves transcriptional regulation of key cell adhesion factor vinculin. Nucleic Acids Res. 2014; 42:11589-11600.

95. Hoffman PC, Mauer AM, Vokes EE. Lung cancer. Lancet. 2000; 355:479-485.

96. Gupta GP, Massague J. Cancer metastasis: building a framework. Cell. 2006; 127:679-695.

97. Hill SM, Belancio VP, Dauchy RT, Xiang S, Brimer S, Mao L, Hauch A, Lundberg PW, Summers W, Yuan L, Frasch T, Blask DE. Melatonin: an inhibitor of breast cancer. Endocr Relat Cancer. 2015; 22:R183-204.

98. Wu SM, Lin WY, Shen CC, Pan HC, Keh-Bin W, Chen YC, Jan YJ, Lai DW, Tang SC, Tien HR, Chiu CS, Tsai TC, Lai YL, Sheu ML. Melatonin set out to ER stress signaling thwarts epithelial mesenchymal transition and peritoneal dissemination via calpain-mediated C/EBPbeta and NFkappaB cleavage. J Pineal Res. 2016; 60:142-154.

99. Ortiz-Lopez L, Morales-Mulia S, Ramirez-Rodriguez G, Benitez-King G. ROCK-regulated cytoskeletal dynamics participate in the inhibitory effect of melatonin on cancer cell migration. J Pineal Res. 2009; 46:15-21.

100. Wang T, Liu G, Wang R. The Intercellular Metabolic Interplay between Tumor and Immune Cells. Front Immunol. 2014; 5:358.

101. Smyth MJ, Dunn GP, Schreiber RD. Cancer immunosurveillance and immunoediting: the roles of immunity in suppressing tumor development and shaping tumor immunogenicity. Adv Immunol. 2006; 90:1-50.

102. June $\mathrm{CH}$. Adoptive $\mathrm{T}$ cell therapy for cancer in the clinic. $\mathrm{J}$ Clin Invest. 2007; 117:1466-1476.

103. Kershaw MH, Westwood JA, Darcy PK. Gene-engineered T cells for cancer therapy. Nat Rev Cancer. 2013; 13:525-541.

104. Carrillo-Vico A, Lardone PJ, Alvarez-Sanchez N, Rodriguez-Rodriguez A, Guerrero JM. Melatonin: buffering the immune system. Int J Mol Sci. 2013; 14:8638-8683.

105. Calvo JR, Gonzalez-Yanes C, Maldonado MD. The role of melatonin in the cells of the innate immunity: a review. J Pineal Res. 2013; 55:103-120.

106. Guerrero JM, Reiter RJ. Melatonin-immune system relationships. Curr Top Med Chem. 2002; 2:167-179.

107. Espino J, Pariente JA, Rodriguez AB. Oxidative stress and immunosenescence: therapeutic effects of melatonin. Oxid Med Cell Longev. 2012; 2012:670294.

108. Sainz RM, Mayo JC, Uria H, Kotler M, Antolin I, Rodriguez C, Menendez-Pelaez A. The pineal neurohormone melatonin prevents in vivo and in vitro apoptosis in thymocytes. J Pineal Res. 1995; 19:178-188.

109. Hoijman E, Rocha Viegas L, Keller Sarmiento MI, Rosenstein RE, Pecci A. Involvement of Bax protein in the prevention of glucocorticoid-induced thymocytes apoptosis by melatonin. Endocrinology. 2004; 145:418-425. 
110. Tian YM, Zhang GY, Dai YR. Melatonin rejuvenates degenerated thymus and redresses peripheral immune functions in aged mice. Immunol Lett. 2003; 88:101-104.

111. Provinciali M, Di Stefano G, Bulian D, Tibaldi A, Fabris N. Effect of melatonin and pineal grafting on thymocyte apoptosis in aging mice. Mech Ageing Dev. 1996; 90:1-19.

112. Tian YM, Li PP, Jiang XF, Zhang GY, Dai YR. Rejuvenation of degenerative thymus by oral melatonin administration and the antagonistic action of melatonin against hydroxyl radical-induced apoptosis of cultured thymocytes in mice. J Pineal Res. 2001; 31:214-221.

113. Maestroni GJ, Conti A, Lissoni P. Colony-stimulating activity and hematopoietic rescue from cancer chemotherapy compounds are induced by melatonin via endogenous interleukin 4. Cancer Res. 1994; 54:4740-4743.

114. Maestroni GJ, Covacci V, Conti A. Hematopoietic rescue via $\mathrm{T}$-cell-dependent, endogenous granulocytemacrophage colony-stimulating factor induced by the pineal neurohormone melatonin in tumor-bearing mice. Cancer Res. 1994; 54:2429-2432.

115. Currier NL, Sun LZ, Miller SC. Exogenous melatonin: quantitative enhancement in vivo of cells mediating nonspecific immunity. J Neuroimmunol. 2000; 104:101-108.

116. Arias J, Melean E, Valero N, Pons H, Chacin-Bonilla L, Larreal Y, Bonilla E. Effect of melatonin on lymphocyte proliferation and production of interleukin-2 (IL-2) and interleukin-1 beta (IL-1 beta) in mice splenocytes. Invest Clin. 2003; 44:41-50.

117. Garcia-Maurino S, Gonzalez-Haba MG, Calvo JR, Goberna $\mathrm{R}$, Guerrero JM. Involvement of nuclear binding sites for melatonin in the regulation of IL- 2 and IL-6 production by human blood mononuclear cells. J Neuroimmunol. 1998; 92(1-2):76-84.

118. Garcia-Maurino S, Gonzalez-Haba MG, Calvo JR, Rafii-ElIdrissi M, Sanchez-Margalet V, Goberna R, Guerrero JM. Melatonin enhances IL-2, IL-6, and IFN-gamma production by human circulating CD4+ cells: a possible nuclear receptor-mediated mechanism involving $\mathrm{T}$ helper type 1 lymphocytes and monocytes. J Immunol. 1997; 159:574581.

119. Garcia-Maurino S, Pozo D, Carrillo-Vico A, Calvo JR, Guerrero JM. Melatonin activates Th1 lymphocytes by increasing IL-12 production. Life Sci. 1999; 65:2143-2150.

120. Vijayalaxmi, Reiter RJ, Tan DX, Herman TS, Thomas CR, Jr. Melatonin as a radioprotective agent: a review. Int J Radiat Oncol Biol Phys. 2004; 59:639-653.

121. Nordlund JJ, Lerner AB. The effects of oral melatonin on skin color and on the release of pituitary hormones. J Clin Endocrinol Metab. 1977; 45:768-774.

122. Kontek R, Nowicka H. The modulatory effect of melatonin on genotoxicity of irinotecan in healthy human lymphocytes and cancer cells. Drug Chem Toxicol. 2013; 36:335-342.

123. Norsa A, Martino V. Somatostatin, retinoids, melatonin, vitamin D, bromocriptine, and cyclophosphamide in chemotherapy-pretreated patients with advanced lung adenocarcinoma and low performance status. Cancer Biother Radiopharm. 2007; 22:50-55.

124. Fic M, Podhorska-Okolow M, Dziegiel P, Gebarowska E, Wysocka T, Drag-Zalesinska M, Zabel M. Effect of melatonin on cytotoxicity of doxorubicin toward selected cell lines (human keratinocytes, lung cancer cell line A-549, laryngeal cancer cell line Hep-2). In Vivo. 2007; 21:513518.

125. Lu JJ, Fu L, Tang Z, Zhang C, Qin L, Wang J, Yu Z, Shi D, Xiao X, Xie F, Huang W, Deng W. Melatonin inhibits AP-2beta/hTERT, NF-kappaB/COX-2 and Akt/ERK and activates caspase/Cyto $\mathrm{C}$ signaling to enhance the antitumor activity of berberine in lung cancer cells. Oncotarget. 2016; 7:2985-3001. doi: 10.18632/oncotarget.6407.

126. Fumagalli L, Lissoni P, Di Felice G, Meregalli S, Valsuani G, Mengo S, Rovelli F. Pretreatment serum markers and lymphocyte response to interleukin-2 therapy. Br J Cancer. 1999; 80(3-4):407-411.

127. Lissoni P, Brivio F, Fumagalli L, Messina G, Vigore L, Parolini D, Colciago M, Rovelli F. Neuroimmunomodulation in medical oncology: application of psychoneuroimmunology with subcutaneous low-dose IL-2 and the pineal hormone melatonin in patients with untreatable metastatic solid tumors. Anticancer Res. 2008; 28(2b):1377-1381.

128. Lissoni P, Barni S, Mandala M, Ardizzoia A, Paolorossi F, Vaghi M, Longarini R, Malugani F, Tancini G. Decreased toxicity and increased efficacy of cancer chemotherapy using the pineal hormone melatonin in metastatic solid tumour patients with poor clinical status. Eur J Cancer. 1999; 35:1688-1692.

129. Lissoni P, Paolorossi F, Ardizzoia A, Barni S, Chilelli M, Mancuso M, Tancini G, Conti A, Maestroni GJ. A randomized study of chemotherapy with cisplatin plus etoposide versus chemoendocrine therapy with cisplatin, etoposide and the pineal hormone melatonin as a first-line treatment of advanced non-small cell lung cancer patients in a poor clinical state. J Pineal Res. 1997; 23:15-19.

130. Sookprasert A, Johns NP, Phunmanee A, Pongthai P, Cheawchanwattana A, Johns J, Konsil J, Plaimee P, Porasuphatana S, Jitpimolmard S. Melatonin in patients with cancer receiving chemotherapy: a randomized, doubleblind, placebo-controlled trial. Anticancer Res. 2014; 34:7327-7337.

131. Lissoni P, Tancini G, Barni S, Paolorossi F, Ardizzoia A, Conti A, Maestroni G. Treatment of cancer chemotherapyinduced toxicity with the pineal hormone melatonin. Support Care Cancer. 1997; 5:126-129.

132. Del Fabbro E, Dev R, Hui D, Palmer L, Bruera E. Effects of melatonin on appetite and other symptoms in patients with advanced cancer and cachexia: a double-blind placebocontrolled trial. J Clin Oncol. 2013; 31:1271-1276.

133. Yun M, Kim EO, Lee D, Kim JH, Kim J, Lee H, Lee J, Kim SH. Melatonin sensitizes H1975 non-small-cell lung cancer 
cells harboring a T790M-targeted epidermal growth factor receptor mutation to the tyrosine kinase inhibitor gefitinib. Cell Physiol Biochem. 2014; 34:865-872.

134. Kobayashi S, Boggon TJ, Dayaram T, Janne PA, Kocher O, Meyerson M, Johnson BE, Eck MJ, Tenen DG, Halmos B. EGFR mutation and resistance of non-small-cell lung cancer to gefitinib. N Engl J Med. 2005; 352:786-792.

135. Steuer CE, Ramalingam SS. Targeting EGFR in lung cancer: Lessons learned and future perspectives. Mol Aspects Med. 2015; 45:67-73.

136. Sequist LV, Waltman BA, Dias-Santagata D, Digumarthy S, Turke AB, Fidias P, Bergethon K, Shaw AT, Gettinger S, Cosper AK, Akhavanfard S, Heist RS, Temel J, Christensen JG, Wain JC, Lynch TJ, et al. Genotypic and histological evolution of lung cancers acquiring resistance to EGFR inhibitors. Sci Transl Med. 2011; 3:75ra26.

137. Pfister DG, Johnson DH, Azzoli CG, Sause W, Smith TJ, Baker S, Jr., Olak J, Stover D, Strawn JR, Turrisi AT, Somerfield MR. American Society of Clinical Oncology treatment of unresectable non-small-cell lung cancer guideline: update 2003. J Clin Oncol. 2004; 22:330-353.

138. Clinical practice guidelines for the treatment of unresectable non-small-cell lung cancer. Adopted on May 16, 1997 by the American Society of Clinical Oncology. J Clin Oncol. 1997; 15:2996-3018.

139. Tan DX, Chen LD, Poeggeler B, Manchester LC, Reiter RJ. Melatonin: A potent, endogenous hydroxyl radical scavenger. Endocrine J. 1993; 1:57-60.

140. Mihandoost E, Shirazi A. Can melatonin help us in radiation oncology treatments? 2014; 2014:578137.

141. Karbownik M, Reiter RJ. Antioxidative effects of melatonin in protection against cellular damage caused by ionizing radiation. Proc Soc Exp Biol Med. 2000; 225:9-22.

142. Reiter RJ, Tan DX, Galano A. Melatonin: exceeding expectations. Physiology (Bethesda). 2014; 29:325-333.

143. Jang SS, Kim HG, Lee JS, Han JM, Park HJ, Huh GJ, Son CG. Melatonin reduces X-ray radiation-induced lung injury in mice by modulating oxidative stress and cytokine expression. Int J Radiat Biol. 2013; 89:97-105.

144. Tahamtan R, Shabestani Monfared A, Tahamtani Y, Tavassoli A, Akmali M, Mosleh-Shirazi MA, Naghizadeh MM, Ghasemi D, Keshavarz M, Haddadi GH. Radioprotective effect of melatonin on radiation-induced lung injury and lipid peroxidation in rats. Cell J. 2015; 17:111-120.

145. Vijayalaxmi, Meltz ML, Reiter RJ, Herman TS, Kumar KS. Melatonin and protection from whole-body irradiation: survival studies in mice. Mutat Res. 1999; 425:21-27.

146. Wang Z, Dabrosin C, Yin X, Fuster MM, Arreola A, Rathmell WK, Generali D, Nagaraju GP, El-Rayes B, Ribatti D, Chen YC, Honoki K, Fujii H, Georgakilas AG, Nowsheen S, Amedei A, et al. Broad targeting of angiogenesis for cancer prevention and therapy. Semin Cancer Biol. 2015; 35 Suppl:S224-243.

147. Cao Y. VEGF-targeted cancer therapeutics-paradoxical effects in endocrine organs. Nat Rev Endocrinol. 2014; 10:530-539.

148. Dai M, Cui P, Yu M, Han J, Li H, Xiu R. Melatonin modulates the expression of VEGF and HIF-1 alpha induced by $\mathrm{CoCl} 2$ in cultured cancer cells. J Pineal Res. 2008; 44:121-126.

149. Jardim-Perassi BV, Lourenco MR, Doho GM, Grigolo IH, Gelaleti GB, Ferreira LC, Borin TF, Moschetta MG, Pires de Campos Zuccari DA. Melatonin Regulates Angiogenic Factors under Hypoxia in Breast Cancer Cell Lines. Anticancer Agents Med Chem. 2016; 16:347-358.

150. Sohn EJ, Won G, Lee J, Lee S, Kim SH. Upregulation of miRNA3195 and miRNA374b Mediates the AntiAngiogenic Properties of Melatonin in Hypoxic PC-3 Prostate Cancer Cells. J Cancer. 2015; 6:19-28.

151. Cho SY, Lee HJ, Jeong SJ, Lee HJ, Kim HS, Chen CY, Lee $\mathrm{EO}, \mathrm{Kim} \mathrm{SH}$. Sphingosine kinase 1 pathway is involved in melatonin-induced HIF-1alpha inactivation in hypoxic PC-3 prostate cancer cells. J Pineal Res. 2011; 51:87-93.

152. Park JW, Hwang MS, Suh SI, Baek WK. Melatonin downregulates HIF-1 alpha expression through inhibition of protein translation in prostate cancer cells. J Pineal Res. 2009; 46:415-421.

153. Wang RX, Liu H, Xu L, Zhang H, Zhou RX. Involvement of nuclear receptor RZR/RORgamma in melatonin-induced HIF-1alpha inactivation in SGC-7901 human gastric cancer cells. Oncol Rep. 2015; 34:2541-2546.

154. Park SY, Jang WJ, Yi EY, Jang JY, Jung Y, Jeong JW, Kim YJ. Melatonin suppresses tumor angiogenesis by inhibiting HIF-1alpha stabilization under hypoxia. J Pineal Res. 2010; 48:178-184.

155. Carbajo-Pescador S, Ordonez R, Benet M, Jover R, GarciaPalomo A, Mauriz JL, Gonzalez-Gallego J. Inhibition of VEGF expression through blockade of Hiflalpha and STAT3 signalling mediates the anti-angiogenic effect of melatonin in HepG2 liver cancer cells. Br J Cancer. 2013; 109:83-91.

156. Lv D, Cui PL, Yao SW, Xu YQ, Yang ZX. Melatonin inhibits the expression of vascular endothelial growth factor in pancreatic cancer cells. Chin J Cancer Res. 2012; 24:310316.

157. Cui P, Yu M, Peng X, Dong L, Yang Z. Melatonin prevents human pancreatic carcinoma cell PANC-1-induced human umbilical vein endothelial cell proliferation and migration by inhibiting vascular endothelial growth factor expression. J Pineal Res. 2012; 52:236-243.

158. Mueller MM, Fusenig NE. Friends or foes - bipolar effects of the tumour stroma in cancer. Nat Rev Cancer. 2004; 4:839-849. 
159. Bremnes RM, Donnem T, Al-Saad S, Al-Shibli K, Andersen S, Sirera R, Camps C, Marinez I, Busund LT. The role of tumor stroma in cancer progression and prognosis: emphasis on carcinoma-associated fibroblasts and nonsmall cell lung cancer. J Thorac Oncol. 2011; 6:209-217.

160. Kim GD, Lee SE, Kim TH, Jin YH, Park YS, Park CS. Melatonin suppresses acrolein-induced IL- 8 production in human pulmonary fibroblasts. J Pineal Res. 2012; 52:356364.

161. Massague J. TGFbeta in Cancer. Cell. 2008; 134:215-230.

162. Wang W, Li Q, Yamada T, Matsumoto K, Matsumoto I, Oda M, Watanabe G, Kayano Y, Nishioka Y, Sone S, Yano S. Crosstalk to stromal fibroblasts induces resistance of lung cancer to epidermal growth factor receptor tyrosine kinase inhibitors. Clin Cancer Res. 2009; 15:6630-6638.
163. El-Nikhely N, Larzabal L, Seeger W, Calvo A, Savai R. Tumor-stromal interactions in lung cancer: novel candidate targets for therapeutic intervention. Expert Opin Investig Drugs. 2012; 21:1107-1122.

164. Anisimov VN, Vinogradova IA, Panchenko AV, Popovich IG, Zabezhinski MA. Light-at-night-induced circadian disruption, cancer and aging. Curr Aging Sci. 2012; 5:170177.

165. Kannen V, Marini T, Zanette DL, Frajacomo FT, Silva GE, Silva WA, Jr., Garcia SB. The melatonin action on stromal stem cells within pericryptal area in colon cancer model under constant light. Biochem Biophys Res Commun. 2011; 405:593-598.

166. Sanchez-Barcelo EJ, Mediavilla MD, Alonso-Gonzalez C, Rueda N. Breast cancer therapy based on melatonin. Recent Pat Endocr Metab Immune Drug Discov. 2012; 6:108-116. 